\title{
Washington Hottine
}

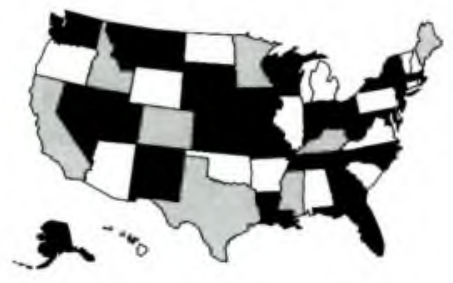

Carol C. Henderson

(202) 547-4440; (ALA0025)

\section{Deputy Director, ALA Washington Office}

RUST V. SULLIVAN. The ramifications for freedom of speech of the Supreme Court decision in RUST V. SULLIVAN are prompting congressional concern and action. The May 23 court decision upheld federal regulations which bar employees of federally funded family planning clinics from discussing abortion with their patients. The majority opinion said abortion counseling was available in clinics funded without federal assistance, and that the government could, through its funding, encourage certain activities to the exclusion of others.

ALA had joined with the Freedom to Read Foundation and others in filing before the Supreme Court an AMICUS brief supporting health-care providers who challenged the regulations as unconstitutional. While the court recognized universities to be exceptions as spheres of free expression, concerns remain that RUST might be applied to other government-funded programs where free inquiry, scholarship, and research are involved, making viewpoint discrimination legitimate when consistent with agencies' governing statutes. ALA is participating in an informal coalition with other groups to try to head off this possibility.

The Senate passed on July 17 a bill to overturn RUST. Introduced by Sen. John Chafee (R-RI), S. 323 would allow clinics funded under title X of the Public Health Service Act to provide pregnant women with information and nondirective counseling services concerning all legal and medical options regarding their pregnancies, including abortion. In passing HR 2707, a bill funding labor, health, and education programs, on June 26, the House approved an amendment sponsored by Rep. John Porter (R-IL) which would prohibit use of appropriated funds in FY 1992 to enforce the 1988 regulations. Neither of these actions is final as yet, but both received bipartisan support. Despite the threat of a presidential veto, the freedom of speech issue troubled many legislators, no matter what their position on abortion.

The Senate Judiciary Subcommittee on the Constitution held a hearing on July 30 on the First Amendment implications of the RUST decision. Judith Krug, Director of ALA's Office for Intellectual Freedom, joined witnesses from the legal, medical, and public interest communities who all agreed that the decision abridged First Amendment rights. Krug attached to her testimony a Resolution Supporting Access to Information on Family Planning and Abortion (CD \#62.12) adopted by the ALA Council on July 3,1991 .

Krug documented ALA's concern about the broad implications of the decision by citing a case currently in litigation, BULLFROG FILMS V. WICK, which challenged regulations issued by the U.S. Information Agency regarding the certification of films as educational for export purposes. In this case pending before the U.S. Court of Appeals for the Ninth Circuit, the U.S. government has sent a supplemental letter contending that the RUST decision permits the government to attach ideological strings to the granting of a certificate attesting to the educational value of films.

Subcommittee chairman and long-time library supporter Paul Simon (D-IL) questioned witnesses about whether, under RUST, libraries' receipt of funds under the Library Services and Construction Act could permit the government to influence book selection, or whether federal funding of universities could give the government a voice in the curriculum.

Leslie Southwick, deputy assistant attorney general, Department of Justice, said that the fact that a decision impacted on speech was not proof that the decision was against the First Amendment. One of the 
principles that RUST continues, according to Southwick, is that the government can determine whether it will sponsor or fund certain activities. "In a sense, when the government funds a certain view, the government itself is speaking. It therefore may constitutionally determine what is to be said."

In the area of federal education, training, and library laws, long-standing provisions specifically prohibit federal influence over curriculum or selection of library materials. For instance, both the Department of Education Organization Act and the General Education Provisions Act prohibit federal "direction, supervision, or control over the curriculum, program of instruction, administration, or personnel of any educational institution, school, or school system, over any accrediting agency or association, or over the selection or content of library resources, textbooks, or other instructional materials by any educational institution or school system." Similarly, the Library Services and Construction Act reserves to state and local initiative the administration of libraries and the selection of personnel and library materials.

\section{American Memory Project test sites named}

Librarian of Congress James $\mathrm{H}$. Billington announced in May that 37 schools, libraries, and research institutions from throughout the nation have been selected as new sites to help test the American Memory Program, which will disseminate computerized versions of Library of Congress collections. The program provides access to collections that pertain to American history and culture; it uses new technologies to disseminate electronic copies of archival photographs, manuscripts, music, motion pictures, books, and sound recordings to libraries and other institutions across the United States. The 37 new sites include: Arizona State University, Tempe; Barnard College, New York, NY; Bismarck Public Schools, Bismarck, ND; Buffalo and Erie County Historical Society, Buffalo, NY; California State Library, Sacramento; Charles Blackstock Junior High, Oxnard, CA; College Grove School, College Grove, TN; Columbia Public Schools, Columbia, MO; East Carolina University., Greenville, NC; East Central Independent School District, San Antonio, TX; Educational School District 113, Olympia, WA; Enoch Pratt Free Library, Baltimore, MD; Fox Hill Elementary School, Indianapolis, IN; Gibraltar Area Schools, Fish Creek, WI; Hampton University, Hampton, VA; Jefferson Davis Parish Library, Jennings, LA; Liverpool Public Library, Liverpool, NY; Lubbock Independent School District, Lubbock, TX; Miami University, Oxford, $\mathrm{OH}$; New Mexico State University, Las Cruces; Oklahoma Department of Libraries, Oklahoma City; Public Library of Charlotte and Mecklenburg County, Charlotte, NC; Reed High School, Sparks, NV; Ruby M. Sisson Memorial Library, Pagosa Springs, CO; Simmons College Library School, Boston, MA; Sioux Falls Public Library, Sioux Falls, SD; St. Mark's High School, Wilmington, DE; St. Petersburg Junior College, Pinellas Park, FL; Sussex County Vocational Tech- nical, Georgetown, DE; the Newberry Library, Chicago, IL; University of Colorado, Boulder; University of Georgia, Athens; University of Montana, Missoula; University of San Diego, CA; Wayne State University, Detroit, MI; West Chester University, West Chester, PA; and Yuma School District One, Yuma, AZ. The evaluation will also be carried out at seven sites that participated in an early round of testing: Andrew Camegie Middle School, Orangevale, CA; Binghamton High School, Binghamton, NY; Brigham Young University, Provo, UT; Northwestern University, Evanston, IL; Oakton High School, Vienna, VA; United States Naval Academy, Annapolis, MD; and West Virginia University, Morgantown, WV. The American Memory prototype to be evaluated will include 267 documents of the Continental Congress and Constitutional Convention; 1,000 photographs of the Civil War by photographer Mathew Brady and others; 500 political cartoons about the U.S. Congress from $1770-1981 ; 60$ sound recordings of America's leaders from the early 20th century; the texts and illustrations of over 300 rare pamphlets written by African-Americans; and early motion pictures of President William McKinley. Software is provided to access cataloging information about each item and printed guides enhance educational use. A special team of LC staff members will supervise the evaluation while information from participating sites will be collected by telephone, questionnaire, and site visits. A special electronic "note pad" feature will allow users to record their comments about the prototype as they work. All of the information collected will contribute to the refinement of the program. "Our American Memory program is an experimental 'vitamin enrichment program' for American education," said Billington. "It is designed to prompt students to seek out more information in their own school or public library." 